\title{
Pencapaian Standar Isi: Tantangan Bagi Guru Madrasah
}

\author{
Euis Rosita, Chaerul Rochman, Ida Farida, Agus Salim Mansur \\ UIN Sunan Gunung Djati Bandung, Jl. Soekarno-Hatta, Cimencrang, Gedebage, Bandung \\ Correspondence Email: euisrosita8oo@gmail.com
}

\begin{abstract}
This study aims to determine the achievement of the Contents Standards through the understanding of PAI and Non PAI teachers in each Indicator. The Population in this study is Madrasah Ibtidaiyah in Tasikmalaya Regency and its samples are MI Tarbiyatul Ula and MI Al-Muawanah. This research method uses descriptive quantitative. Data collection techniques using observation, questionnaire documentation and data analysis. Data collection and observation using google form distributed to 5 PAI teachers and 5 Non PAI teachers. Collecting authentic data and triangulating interview results with several teachers and analyzing the results of comparisons between PAI and Non PAI teachers. The results of this study indicate that achievement of the contents of 84,50 \% for PAI teachers and 82,00 \% for Non PAI teachers. This shows the level of achievement of the Contents Standards through teacher understanding through each indicator is still lacking and needs to be improved by following various training and teacher readiness to improve performance. Islamic Religious Education (PAI) Teachers and Non PAI Teachers must be able to increase their selfactualization through various trainings as additional knowledge and experience in order to increase their professionalism.s
\end{abstract}

Keywords:

Achievement Content Standard; Islamic Education; Profile of Teacher Competence

\begin{abstract}
Abstrak
Penelitian ini bertujuan untuk mengetahui pencapaian Standar Isi melalui pemahaman guru PAI dan Non PAI pada setiap Indikatornya. Populasi pada penelitian ini adalah Madrasah Ibtidaiyah di Kabupaten Tasikmalaya dan sampel nya yaitu MI Tarbiyatul Ula dan MI Al-Muawanah. Metode penelitian ini menggunakan Kuantitatif Deskriptif. Teknik pengumpulan data menggunakan observasi, dokumentasi angket dan analisis data. Pengambilan data dan observasi menggunakan google form yang disebar kepada 5 guru PAI dan 5 guru Non-PAI. Mengumpulkan data otentik dan triangulasi hasil wawancara dengan beberapa guru dan menganalisis hasil perbandingan antara guru PAI dan Non-PAI. Hasil penelitian menunjukkan perbandingan pemahaman standar Isi sebesar 84,50 \% untuk guru PAI dan 82,00 \% untuk guru Non PAI. Hal ini menunjukkan tingkat pencapaian Standar Isi melalui pemahaman guru melalui tiap indikatornya masih kurang dan perlu ditingkatkan dengan mengikuti berbagai pelatihan dan kesiapan guru untuk memperbaiki kinerjanya. Guru Pendidikan Agama Islam (PAI) maupun Guru Non PAI harus bisa meningkatkan aktualisasi dirinya melalui berbagai pelatihan sebagai tambahan ilmu dan pengalaman dalam rangka meningkatkan profesionalitasnya.
\end{abstract}

Kata Kunci:

Pencapaian Standar Isi; Pendidikan Agama Islam; ProfilPemahaman Guru

\section{Pendahuluan}

Salah satu komponen yang penting dalam pendidikan adalah sistem standarisasi. Pemahaman terhadap standar isi pendidikan saat ini belum merata, termasuk oleh para tenaga pendidik dan kependidikan. Kebijakan pemerintah tentang standar isi menjadi salah satu kompetensi yang harus dimiliki oleh segenap tenaga pendidik. Namun, masih banyak yang belum memahami dan mengimplementasikan standar tersebut dalam tugas sehari-hari. (Jaya, 2019) 
mengatakan Implementasi standar isi sangat diharapkan oleh masyarakat.

Terkait dengan beberapa kebijakan standar isi di atas, terdapat dalam Peraturan Pemerintah No. 19 Tahun 2005 tentang Standar Nasional Pendidikan Bab III pasal 5 ayat 1 dan 2 yang memuat Kerangka dasar dan struktur Kurikulum, beban belajar dan kalender pendidikan, untuk mencapai kompetensi lulusan sesuai jenjang pendidikan tertentu (Ulum, 2020).

Ada beberapa penelitian yang telah dilakukan terkait dengan pemahaman dan implementasi standar isi dalam proses pendidikan di sekolah. Seperti (Oktradiksa, 2017) menyimpulkan bahwa masih rendahnya pemahaman pengetahuan guru tentang standar isi sehingga membutuhkan pendampingan yang akurat agar menghasilkan lulusan yang kompeten melalui pembelajaran yang kreatif. Demikian pula (Wahyuni, 2017) menyimpulkan bahwa salah satu faktor lemahnya implementasi standar isi adalah kurangnya pemahaman terhadap setiap indikator Standar isi mulai dari pengembangan pembelajaran sampai pengembangan kurikulum. Menurut penelitian (Ibrahim 2017). Dalam rangka menyikapi permasalahan tersebut Kemendikbud telah menyelenggarakan program peningkatan Kompetensi Guru Pembelajar, dengan maksud untuk meningkatkan kompetensi pedagogik dan profesional guru.

Berdasarkan informasi dan temuantemuan tentang standar isi di atas, maka pentingnya dilakukan pengkajian atau penelitian atau penelusuran tentang pemahaman guru terhadap standar isi. Guru Pendidikan Agama Islam (PAI) merupakan salah satu sasaran penelitian dalam memahami standar isi, hal ini untuk membuktikan keprofesionalan guru PAI dalam pekerjaannya. Tujuan penelitian ini adalah untuk mengungkap dan mengkaji pemahaman standar isi dari guru PAI dan guru Non PAI.

Pendidikan di Indonesia berlandaskan Pancasila dan Undang-Undang Dasar 1945 yang bertujuan untuk mencerdaskan kehidupan bangsa. Dalam hal ini peserta didik mampu menjadi apa yang diharapkan melalui terbinanya pendidikan dari dalam dokumen standar isi sebagaimana yang dimaksud oleh peraturan pemerintah No. 19 tahun 2005. Pada hakekatnya pengaturan Standar Pendidikan dimaksudkan untuk memastikan setiap lembaga pendidikan memiliki kelayakan sebagai lembaga yang memberikan pelayanan yang optimal, Sehingga setiap lembaga pendidikan wajib memiliki semua layanan dengan mengacu kepada 8 standar nasional pendidikan.

Sebagaimana yang telah ditegaskan dalam undang-undang diatas, setiap satuan pendidikan wajib mengembangkan perangkat pembelajaran (bahan ajar) pada kompetensi sikap spiritual, sosial, pengetahuan dan keterampilan peserta didik. Juga sekolah harus dapat mengembangkan perangkat Pendidikan agama dan budi pekerti (Zulfitria 2017) menurutnya pendidikan agama sangat penting dalam proses pembentukan akhlak mulia sehingga menumbuhkan karakter baik bagi anak bangsa. Selain itu, guru harus bisa mengembangkan perangkat pembelajaran tematik terintegrasi pada setiap jenjang kelas. Disamping itu sekolah harus dapat menyusun KTSP, mengembangkan kurikulum sesuai tahapan-tahapannya dalam pedoman pengembangan KTSP dengan melibatkan semua stakeholder dan melaksanakan Kurikulum sesuai dengan ketentuan (Saajidah, 2018).

Peneliti tertarik meneliti standar isi adalah karena mengharapkan pencapaian yang seimbang antara guru PAI dan guru non-PAI, karena PAI itu sendiri harus bisa menyesuaikan terhadap perkembangan 
zaman, situasi serta kondisi yang dianalisis di Kabupaten Tasikmalaya tingkat Madrasah Ibtidaiyah (MI). Tujuan dari penelitian ini adalah untuk mengetahui pencapaian Standar Isi disekolah melalui pemahaman guru PAI dan guru Non-PAI terhadap 10 indikator Standar Isi. Sebagai penelitian terdahulu pun belum ada yang menganalisis pencapaian Standar Isi guru PAI dan nonPAI sebagai bentuk acuan dari pemerintah. Adapun peneliti hanya mengambil 5 sample guru PAI dan 5 sample guru non-PAI. Dengan menggunakan metode Kuantitatif Deskriptif.

\section{Metode Penelitian}

Metode yang digunakan dalam Penelitian ini adalah kuantitatif deskriptif (Suryana, 2009). Penelitian ini memaparkan tentang pemahaman guru terhadap Indikator Standar Isi melalui perhitungan persepsi guru terhadap setiap Indikator tersebut.

Madrasah Ibtidaiyah (MI) merupakan Jenjang pendidikan formal paling dasar setingkat Sekolah Dasar (SD) yang pengelolaannya dilakukan oleh Kementrian Agama. Pendidikan Madrasah Ibtidaiyah ditempuh dalam waktu 6 tahun mulai kelas 1 sampai kelas 6. Lulusan Madrasah Ibtidaiyah (MI) dapat melanjutkan pendidikan ke Madrasah Tsanawiyah (MTs) atau Sekolah Menengah Pertama (SMP). Oleh karena itu guru yang ada di Madrasah Ibtidaiyah (MI) bisa dijadikan sasaran penelitian.

Populasi penelitian adalah guru-guru di Madrasah Ibtidaiyah (MI) yaitu guru MI Tarbiyatul Ula yang beralamat di Kp. Cimanganti RT/RW 007/o02 Desa Cimanggu Kecamatan Puspahiang Kabupaten Tasikmalaya dan MI AlMuawanah yang beralamat di Kp. Leuwipeusing RT/RW 013/oo2 Desa Sukanagara Kecamatan Tanjungjaya
Kabupaten Tasikmalaya. Responden yang digunakan adalah 5 (lima) orang guru PAI dan 5 (lima) orang guru Non PAI. Mereka 5 (lima) orang laki-laki dan 2 (dua) orang perempuan dari MI Tarbiyatul Ula, dan 1 (satu) orang laki-laki dan 2 (dua) orang perempuan dari MI Al-Muawanah.

Instrumen yang digunakan adalah angket tentang pemahaman terhadap Standar Isi. Indikator Standar Isi berjumlah 10 (sepuluh) buah yaitu Pengembangan Kompetensi Sikap Spiritual, Sikap Sosial, Pengetahuan, Keterampilan, akhlak dan budi pekerti, pembelajaran tematik, pengembangan kurikulum, menyusun kurikulum, mengembangbangkan kurikulum sesuai prosedur, dan melaksanakan kurikulum.

Adapun tahapan mengolah dan menganalisis data dilakukan dengan tahapan berikut yaitu: (1) menyebar angket lewat Google form yang berisi 10 Indikator Standar Isi dengan 4 (empat) alternatif jawaban, kepada guru PAI dan Non PAI di MI Tarbiyatul Ula dan MI AlMuawanah, (2) Peneliti mendapatkan jawaban kemudian ditentukan penskoran,dan (3) Hasil tersebut diolah menjadi data kuantitatif kemudian dideskripsikan sebagai alat ukur untuk mengambil kesimpulan.

\section{Hasil dan Pembahasan}

Berdasarkan hasil pengolahan data pemahaman guru terhadap Indikator Standar Isi pada MI Tarbiyatul Ula dan MI Al-Muawanah Tasikmalaya, maka berikut ini akan disajikan pembahasan tentang Profil Pemahaman Guru PAI dan Non PAI berdasarkan Indikator, Pembahasan Profil Pemahaman Guru PAI dan Non PAI berdasarkan kelompok guru dan Trianggulasi.

\subsection{Profil Pemahaman Standar Isi Berdasarkan Indikator}


Pemahaman guru PAI dan Non PAI terhadap kesepuluh Indikator Standar Isi akan ditunjukkan melalui diagram batang berikut ini.

\section{Profil Pemahaman Standar Isi berdasarkan Indikator pada Guru PAI (Biru) dan Non PAI (Merah)}

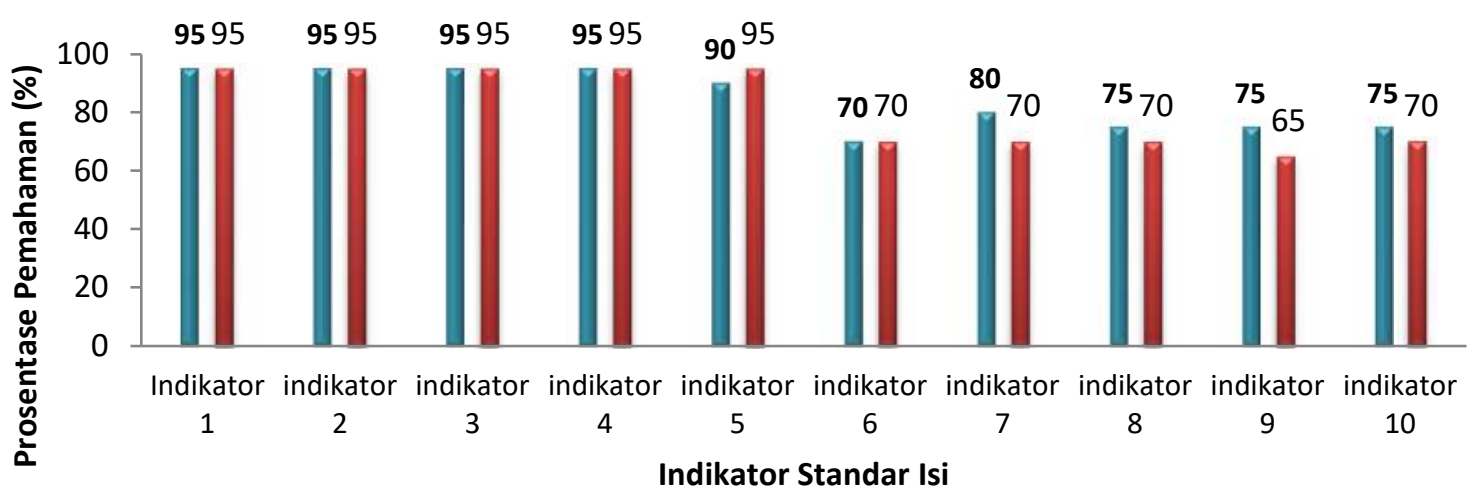

Gambar 1. Profil Pemahaman Standar Isi

Berdasarkan Gambarı. menunjukkan bahwa profil pemahaman guru terhadap standar isi bervariasi. Pada kedua kelompok Guru PAI dan Non PAI prosentase pemahaman terbesar terletak pada Indikator 1, 2, 3, dan 4, yaitu 95\%. Indikator tersebut berkaitan dengan pengembangan pembelajaran sesuai sikap spiritual sosial pengetahuan dan keterampilan. Sedangkan indikator yang paling rendah untuk kelompok Guru PAI terletak pada indikator 6 yang berkaitan dengan pengembangan pembelajaran tematik sesuai jenjang kelas. Sedangkan Untuk kelompok Guru Non PAI terletak pada indikator 9 yang berkaitan dengan pengembangan kurikulum sesuai prosedur.

Profil pemahaman guru terhadap Standar Isi terlihat masih lemah pada Indikator kemampuan dalam mengembangkan perangkat pembelajaran Tematik. Hal ini sejalan dengan hasil penelitian yang menyimpulkan bahwa guru masih memiliki kesulitan dalam melengkapi perangkat pembelajaran Tematik Integratif(Malawi, 2017). Demikian pula menurut penelitian lain yang mengungkapkan bahwa salah satu kelemahan pada guru adalah dalam aspek pengembangan perangkat pembelajaran yang mengacu pada kebijakan Kurikulum (Kusumaningrum, 2017). Sedangkan Guru PAI dan Non PAI mereka sudah memiliki kecenderungan memahami komponen Kurikulum Tingkat Satuan Pendidikan (KTSP). Berkaitan dengan temuantemuan tadi, ditemukan pula oleh Kusumaningrum (2017) bahwa sebagian besar guru di sekolah memahami Komponen KTSP tapi belum menguasai cara mengembangkan KTSP.

Berdasarkan informasi di atas, maka masalah utama yang dihadapi oleh Guru PAI dan Non PAI adalah pada Indikator 6 yaitu dalam mengembangkan perangkat pembelajaran Tematik untuk setiap jenjang kelas. Kelemahan dalam pencapaian standar isi ini ditandai dengan masih lemahnya guru PAI maupun Non 
PAI pada Indikator 9 yaitu mengenai kemampuan dalam pengembangan KTSP.

\subsection{Perbandingan Pemahaman Standar Isi pada Guru.}

Perbandingan pemahaman Standar Isi yang didapat dari Guru PAI dan Non PAI di MI Tarbiyatul Ula dan MI AlMuawanah Tasikmalaya dapat dilihat dalam Grafik berikut ini:

\section{Perbandingan Prosentase Pemahaman Standar Isi}

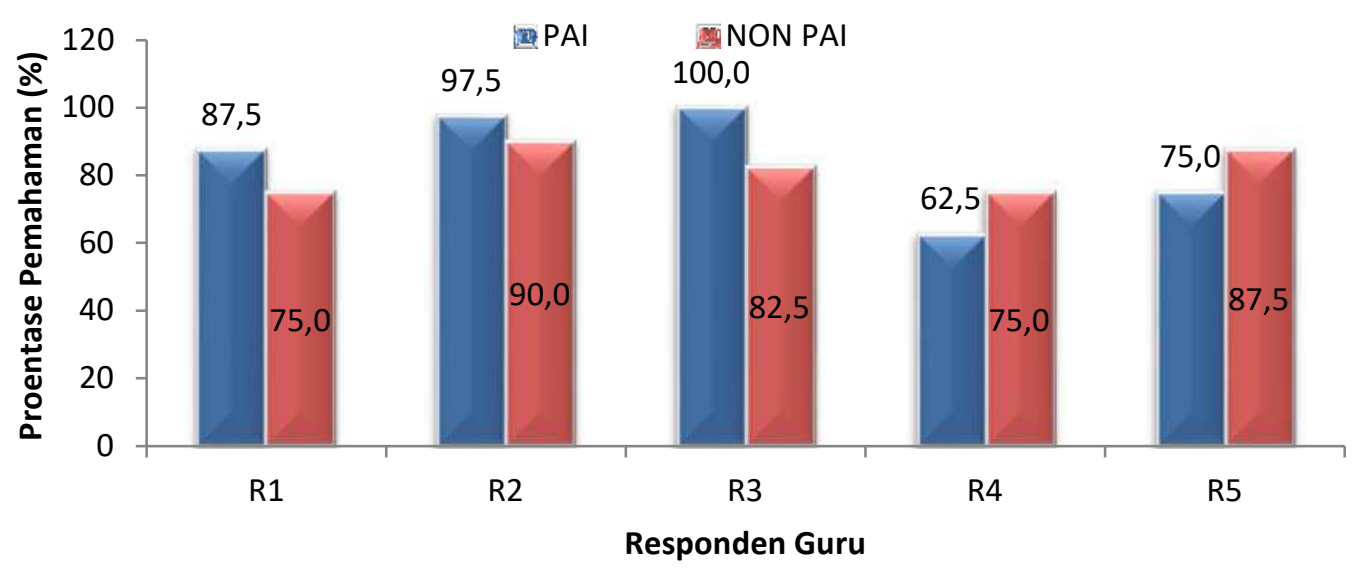

Gambar 2. Perbandingan Prosentase Pemahaman Standar Isi

\section{Perbandingan Rata-rata Pemahaman Standar Isi}

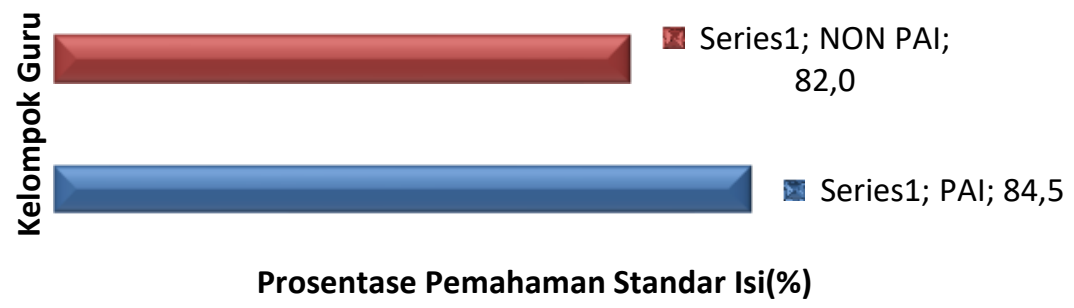

Gambar 3. Perbandingan Rata-rata Pemahaman Standar Isi

Gambar 2 menunjukkan bahwa perbandingan pemahaman Standar Isi berdasarkan kelompok Guru nampak bervariasi. Responden dengan persentase tertinggi pada kelompok Guru PAI diperoleh hasil bahwa Responden ke-tiga yaitu $100 \%$ dan persentase terendah adalah Responden ke-empat yaitu 62,5\%. Sedangkan pada kelompok Guru Non PAI, prosentase tertinggi diperoleh dari Responden ke-2 dengan 90\% dan persentase terendah diperoleh dari Responden kesatu dan keempat dengan $70 \%$. Pada gambar 3 menunjukkan perbandingan rata-rata persentase pemahaman Standar Isi kelompok Guru PAI dan Non PAI. Prosentase pemahaman Standar Isi Guru PAI $(84,5 \%)$ lebih besar dibanding dengan Guru Non PAI $(82,0 \%)$. Perbandingan prosentase pemahaman Standar Isi berdasarkan kelompok guru terlihat pada kelompok 
guru PAI lebih memahami tentang Standar Isi dengan capaian $84,5 \%$. Hal ini sesuai dengan penelitian (Munaris, 2018) bahwa dalam penelitiannya setengahnya dari guru memahami tentang Standar Isi. Tapi prosentase yang masih kurang dalam pemahaman Standar Isi terdapat pada Guru Non PAI dengan capaian 82,0\%. Sesuai dengan (Sumarsono, 2018) bahwa meskipun dalam kategori baik guru masih tetap mengalami kesulitan dalam mengembangkan perangkat pembelajaran.

Berdasarkan informasi di atas, maka masalah utama yang dihadapi oleh Guru PAI dan Non PAI adalah kelemahan dalam mengembangkan perangkat pembelajaran Tematik dan mengembangkan KTSP. Kelemahan ini mungkin diakibatkan oleh jarangnya guru mendapatkan pelatihan paedagogik maupun keterampilan administrasi. Sehingga guru membutuhkan kesiapan untuk mengikuti berbagai pelatihan dalam rangka meningkatkan kinerjanya. Pelatihan dapat mendorong guru memiliki kompetensi yang mumpuni sehingga hasil belajar siswa menjadi lebih baik(Wicaksono, 2018).

\subsection{Triangulasi}

Berdasarkan persentase dari analisis diatas peneliti melakukan Triangulasi. Tujuannya adalah untuk mendalami jawaban dari beberapa orang Responden. Responden terdiri dari 1 (satu) orang Guru PAI dan 2 (dua) orang Guru Non PAI. Adapun untuk Indikator 6 kepada responden 4 yaitu Bapak Muhtar Ghazali untuk guru PAI dan untuk Indikator 9 pada guru non PAI, Responden 1 yaitu Ibu Erna Risnawati dan Responden 4 yaitu Ibu Nina Rusmina. Pertanyaan yang diungkapkan adalah 1) Bagaimana menurut Bapak/Ibu penyebab Indikator rendah, paham/kurang faham, atau ada penyebab lainnya? 2) Bagaimana menurut
Bapak/Ibu cara untuk meningkatkan Indikator tersebut?

Hasil Triangulasi adalah:

a. Responden $4\left(\mathrm{R}_{4}\right)$ yaitu Bapak Muhtar Ghazali beliau adalah Guru PAI yang baru di MI Tarbiyatul Ula Tasikmalaya. Ia mengemukakan bahwa penyebab kondisi indikator 6 rendah dikarenakan beliau kurang memahami isi dari indikator tersebut. Disamping itu, R4 adalah tenaga pengajar yang baru di MI Tarbiyatul ula. Menurut R4, salah satu solusinya adalah dengan mengikuti pelatihan di KKG, terutama dalam mengembangkan perangkat pembelajaran tematik terintegrasi meskipun beliau seorang guru PAI. Pelatihan tersebut diharapkan dapat menghantarkan $\mathrm{R}_{4}$ menjadi guru profesional yang dapat meningkatkan hasil belajar siswa. Pada akhirnya akan dapat menciptakan kemajuan untuk peserta didik di MI Tarbiyatul Ula Tasikmalaya.

b. Responden 1 (R1) yaitu Ibu Erna Risnawati adalah Guru Non PAI di MI Tarbiyatul Ula Tasikmalaya. Ia mengemukakan bahwa penyebab kondisi indikator 9 rendah karena beliau kurang memahami tahapantahapan pengembangan kurikulum meskipun beliau sudah lama menjadi tenaga pendidik tapi kurang memahami dalam bidang administrasi kurikulum cukup menyerahkan kepada bagian operator. Salah satu solusinya adalah $\mathrm{R} 1$ akan selalu berusaha untuk ikut terlibat secara aktif dalam proses pengembangan kurikulum secara bertahap. Sehingga bisa meningkatkan hasil belajar siswa. Selain Itu, dapat memberikan kontribusi yang baik untuk kemajuan peserta didik di MI Tarbiyatul Ula Tasikmalaya.

c. Responden 4 (R4) yaitu Ibu Nina Rusmina beliau adalah Guru Non PAI 
di MI Al-Muawanah Tasikmalaya. Ia mengemukakan bahwa penyebab kondisi indikator 9 rendah karena beliau kurang memahami isi dari indikator tersebut. Salah satu solusi cara meningkatkannya adalah ( $\left.\mathrm{R}_{4}\right)$ akan selalu berusaha untuk ikut terlibat secara aktif dalam proses pengembangan kurikulum yang sesuai dengan prosedur melalui empat tahapan pengembangannya. Sehingga $\mathrm{R}_{4}$ bisa meningkatkan hasil belajar siswa.Selain Itu Dapat memberikan hasil yang baik bagi kemajuan pembelajaran di MI Al-Muawanah Tasikmalaya.

Berdasarkan hasil triangulasi diatas, menunjukkan bahwa performansi pada beberapa indikator masih rendah. Ratarata disebabkan oleh masih barunya mengenal standar isi, juga masih belum mampu memahami secara rinci kualifikasi terbaik dari indikator yang dikehendaki (Jailani \& Rochman, 2019). Sehingga solusinya, mereka menyarankan untuk mendapatkan pelatihan pengembangan kurikulum dan tahapan tahapan pengembangannya.

\section{Simpulan}

Berdasarkan analisis penyajian data dan performnasi pemahaman indikator Standar Isi, dan perbandingan prosentase antara Guru PAI dan Non PAI, dapat disimpulkan bahwa masalah utama yang dihadapi adalah kurangnya pemahaman dalam mengembangkan perangkat pembelajaran tematik terintegrasi. Disamping itu kurangnya pemahaman terhadap pengembangan kurikulum sesuai tahapannya. Masalah ini terjadi karena guru-guru jarang mengikuti pelatihan-pelatihan yang berhubungan dengan pengembangan kurikulum dan implementasinya dalam pembelajaran. Salah satu yang direkomendasikan adalah semua guru harus difasilitasi untuk mengkuti pelatihan, seperti KKG atau pelatihan dalam mengembangkan perangkat pembelajaran tematik. Sedangkan dalam pengembangan Kurikulum semua guru harus terlibat secara aktif mulai dari tahap perencanaan sampai pelaksanaan, serta evaluasi pengembangan sebagai salahsatu cara untuk memperbaiki kinerjanya.

\section{Ucapan Terima Kasih}

Penulis mengucapkan terima kasih sebesar-besarnya kepada Bapak Taupikurahman, S. Pd. I. sebagai Kepala Sekolah MI Tarbiyatul Ula dan Bapak Agus Ridwan, S. Pd. I. sebagai kepala sekolah MI Al-Muawanah yang telah memberikan izin dan berkontribusi sehingga penelitian ini terlaksana.

\section{Daftar Pustaka}

Jailani, A., \& Rochman, C. (2019). Analisis Ketercapaian Standar Isi Pada Sekolah Dasar (SDS Plus Syania Kec. Cimanggung Kab. Sumedang Jawa Barat). JIP (Jurnal Ilmiah PGMI), 5(1), 74-83.

https://doi.org/https://doi.org/10.1910 9/jip.v5i1.3183

Jaya, A. S. (2019). Implementasi Standar Nasional Pendidikan di Kabupaten Aceh. (Ellyawati, Penyunt.) jurnal.abulyatama.ac.id, 3 (1), 1-13.

Kusumaningrum, D. E. (2017). PENDAMPINGAN

PENGEMBANGAN PERANGKAT PEMBELAJARAN BERBASIS KURIKULUM 2013. journal2.um.ac.id, $1(1), 1-6$.

Malawi, I. (2017). Pengembangan Perangkat Pembelajaran Kurikulum 2013 di Sekolah Dasar. journal2.um.ac.id, 2 (1), 1-7.

Munaris. (2018, April 1). Pemahaman Guru Bahasa Indonesia SMA di Kabupaten Mesuji. (B. Riadi, Penyunt.) repository.lppm.unila.ac.id, 19 (1), hal. 54-6o. 
Oktradiksa, A. (2017, September 7). PKU bagi MI Muhammadiyah Madukoro dan Wonogiri Kabupaten Magelang melalui Implementasi Standar Nasional Pendidikan Dasar dalam Pengembangan Mutu Madrasah. Ahwy 2017, hal. 1-20.

Saajidah. (2018). FUNGSI-FUNGSI MANAJEMEN PENGELOLAAN DALAM Journal of Islamic Educational Management, 1 (1), 1-71.

Saajidaha, L. (2018, Juli 1). FUNGSIFUNGSI MANAJEMEN DALAM PENGELOLAAN KURIKULUM. Journal of Islamic Educational Management, hal. 1-7.

Sumarsono. (2018). PERSEPSI GURU MADRASAH IBTIDAIYAH (MI) DALAM MENERAPKAN KURIKULUM 2013 DI KABUPATEN MERAUKE.

journal.staihubbulwathan.id, 10 (2), 115.

Suryana, Y. (2009). Metodologi Penelitian Pendidikan (Cetakan ke 3 ed., Vol. III). (K. Dienan, Penyunt., \& Y. Suyatna, Penerj.) Bandung, Jawa Barat, Indonesia: Agustus 2009.

Ulum, M. (2020). KEBIJAKAN STANDAR NASIONAL PENDIDIKAN. ejournal.kopertais4.or.id, 11 (1), 1-12.
Wahyuni, E. (2017, Mei 24). Efektivitas Pendampingan Guru Sasaran Implementasi Kurikulum 2013 pada Pembelajaran Geografi SMA N di Kabupaten Sragen Tahun Pelajaran 2016/2017. I, hal. 1-39.

Wicaksono. (2018). PENYUSUNAN SOAL TES KURIKULUM KTSP BAGI GURU SD DJAMA'ATUL ICHWAN PROGRAM UTAMA SURAKARTA. ejournal.unisri.ac.id, II (2), 1-5.

Zulfitria (2017), "Peranan Pembelajaran Tahfidz Al-Quran Dalam Pendidikan Karakter di Sekolah Dasar", Naturalistic.Journal umtas.ac.id, Vol. 1, Hal. 124-134

Ibrahim, Teguh (2017), "Profil Karakter Guru Pembelajar: Sebuah Kerangka Konseptual", Naturalistic.Journal umtas.ac.id, Vol. 2, Hal. 8-22

\section{Wawancara}

Ghazali, Muhtar (Guru), wawancara oleh Euis Rosita MI Tarbiyatul Ula. Tanggal 3 Maret 2020.

Risnawati, Erna (Guru), wawancara oleh EuisRosita MI Tarbiyatul Ula. Tanggal 3Maret2020.

Rusmina, Nina (Guru), wawancara oleh Euis Rosita MI Al-Muawanah. Tanggal 5 Maret 2020. 